\title{
PENGARUH PENGGUNAAN PUPUK TERHADAP KUALITAS AIR TANAH DI LAHAN PERTANIAN KAWASAN RAWA RASAU JAYA III, KAB. KUBU RAYA
}

\author{
Uly Fikri ${ }^{1}$, Marsudi ${ }^{2}$, Dian Rahayu Jati ${ }^{1}$ \\ ${ }^{1}$ Program Studi Teknik Lingkungan Jurusan Teknik Sipil Fakultas Teknik Universitas Tanjungpura, Pontianak \\ ${ }^{2}$ Program Studi Teknik Sipil Jurusan Teknik Sipil Fakultas Teknik Universitas Tanjungpura, Pontianak \\ Email: ulyfikri92@gmail.com
}

\begin{abstract}
ABSTRAK
Pada lahan pertanian penggunaan pupuk sangatlah berpengaruh demi kelangsungan hidup tanaman di lahan pertanian, akan tetapi di sisi lain penggunaan pupuk dapat mempengaruhi kualitas air tanah dikarenakan pupuk yang digunakan adalah pupuk kimia atau anorganik salah satunya pupuk NPK. Penelitian ini bertujuan untuk mengetahui pengaruh pupuk NPK (Nitrogen, Fosfor, dan Kalium) dan persentase kenaikan konsentrasi terhadap kualitas air tanah serta mengetahui pola penyebaran yang disebabkan penggunaan pupuk NPK sebelum pemupukan dan 3 (tiga) hari setelah pemupukan di lahan pertanian kawasan rawa Rasau Jaya III, Kecamatan Rasau Jaya, Kabupaten Kubu Raya.

Metode pada penelitian ini adalah melakukan pengukuran kedalaman ke muka air tanah dengan membuat sumur pantau sebanyak 25 (dua puluh lima) buah dengan jarak \pm 50 meter dan menganalisa pola sebaran kedalaman ke muka air tanah, untuk mewakili tingkat pencemaran air tanah diambil 5 (lima) buah sampel kualitas air pada sumur pantau secara diagonal. Pengambilan sampel kualitas air dilakukan pada 2 (dua) fase yaitu saat sebelum pemupukkan dan 3 (tiga) hari setelah pemupukkan, pupuk NPK yang digunakan dengan perbandingan 20:10:10 yaitu 20\% Nitrogen, 10\% Fosfat, dan $10 \%$ Kalium.

Hasil penelitian mendapatkan bahwa kualitas air tanah karena konsentrasi $\mathrm{N}, \mathrm{P}$, dan $\mathrm{K}$ melebihi baku mutu PP RI No.82 Tahun 2001 kelas II, di mana titik konsentrasi tertinggi berada di titik D4. Analisis kualitas air tanah dengan persentase kenaikan tertinggi pada Konsentrasi Nitrogen (N) di titik B2 saat sebelum pemupukkan sebesar sebesar $29,58 \mathrm{mg} / \mathrm{l}$ dan saat setelah pemupukkan sebesar 77,45 mg/l dengan persentase kenaikan 161,83\% (di atas baku mutu). Konsentrasi Fosfor (P) di titik D4 tertinggi saat sebelum pemupukkan sebesar $1,89 \mathrm{mg} / \mathrm{l}$ dan saat setelah pemupukkan $49,03 \mathrm{mg} / \mathrm{l}$ dengan persentase kenaikan $2494,18 \%$ (di atas baku mutu). Konsentrasi Kalium (K) di titik B2 tertinggi saat sebelum pemupukkan sebesar $8,4 \mathrm{mg} / \mathrm{l}$ dan saat setelah pemupukkan sebesar $34,92 \mathrm{mg} / \mathrm{l}$ dengan persentase kenaikan $315,71 \%$. Aliran air tanah di lokasi penelitian mengikuti ketinggian elevasi tanah, mengalir tempat tinggi menuju ke tempat yang rendah membawa kontaminan dan terjadi penyebaran kontaminan pada elevasi tanah yang relatif rendah.
\end{abstract}

Kata Kunci : Air Tanah, Pola Sebaran Kontaminan, Pupuk NPK.

\section{ABSTRACT}

In the agricultural land use of fertilizers is very influential for the survival of plants in farmland, but in other side the use of fertilizers can affect for groundwater quality because the fertilizer used is chemical fertilizer or inorganic fertilizer one of them NPK's fertilizer. This research intend determine the effect of NPK's fertilizer (Nitrogen, Phosphorus, and Potassium) and the percentage increase in the concentration of the groundwater quality and also know the pattern of spread caused the use of NPK's fertilizer before fertilization and 3 (three) days after fertilization in agricultural land area of swamp Rasau Jaya III, Rasau Jaya sub-district, Kubu Raya regency.

Method in this research are measuring the depth to groundwater by making monitoring wells amount 25 (twenty five) with distance \pm 50 meters and analyzing of distribution pattern depth to groundwater, for represent of groundwater level amount 5 (five) samples water quality in monitoring wells diagonally. The sampling is done for 2 (two) phase are before fertilizing and 3 (three) days after fertilizing, NPK's fertilizer is used with comparison 20:10:10 there is 20\% Nitrogen, 10\% Phosphorus, 10\% Potassium.

The result showed that the groundwater quality due concentration of $N, P$, and $K$ is exceeded the quality standard PP RI No. 82 year of 2001 class of II, where the highest concentration in D4's point. The analysis of ground water quality with the highest percentage increase in concentration of Nitrogen at B2's point before fertilizing is $29,58 \mathrm{mg} / \mathrm{l}$ and after fertilizing is $77,45 \mathrm{mg} / \mathrm{l}$ with percentage increase is 
$116,83 \%$ (exceeded quality standard). The highest concentration of Phosphorus at D4's point before fertilizing is $1,84 \mathrm{mg} / \mathrm{l}$ and after fertilizing is $49,03 \mathrm{mg} / \mathrm{l}$ with percentage increase is $2494,18 \%$ (exceeded quality standard). The highest concentration of Potassium at B2's point before fertilizing is $8,4 \mathrm{mg} / \mathrm{l}$ and after fertilizing is $34,92 \mathrm{mg} / \mathrm{l}$ with percentage increase is $315,17 \%$. Groundwater flow at research site following the elevation height of land, high flows to the place where the low carrying contaminants and contaminant scattering occurs at a relatively low ground elevation.

Keyword : Groundwater, Distribution pattern of contaminants, NPK's fertilizer.

\section{PENDAHULUAN}

Pupuk NPK merupakan pupuk majemuk yang mengandung unsur hara utama lebih dari dua jenis dengan kandungan unsur hara nitrogen $15 \%$ dalam bentuk $\mathrm{NH}_{3}$, fosfor $15 \%$ dalam bentuk $\mathrm{P}_{2} \mathrm{O}_{5}$, dan kalium $15 \%$ dalam bentuk $\mathrm{K}_{2} \mathrm{O}$. Pemakaian pupuk anorganik secara terus-menerus dapat berdampak buruk bagi lingkungan terutama terhadap kualitas air tanah sehingga terjadinya pencemaran air tanah. Dampak bagi lingkungan itu sendiri adalah meningkatnya konsentrasi zat pencemar yang menyerap ke permukaan tanah kemudian menyebar ke daerah yang bertekanan rendah yang kemudian di bawa oleh air tanah. Pencemaran air didefinisikan sebagai masuknya atau dimasukkannya makhluk hidup, zat, energi dan atau komponen lain ke dalam air oleh kegiatan manusia sehingga menyebabkan kualitas air turun sampai ke tingkat tertentu yang menyebabkan air tidak berfungsi lagi sesuai dengan peruntukannya (PP RI No.82 Tahun 2001). Penggunaan pupuk NPK di lahan pertanian diaplikasikan di Desa Rasau Jaya III yang merupakan salah satu desa yang terletak di Kecamatan Rasau Jaya yang merupakan salah satu dari 4 (empat) kecamatan kawasan KTM (Kota Terpadu Mandiri) Rasau Jaya.

\section{METODOLOGI PENELITIAN}

Lokasi penelitian berada di kawasan rawa Rasau Jaya III yang termasuk wilayah administratif dari Kecamatan Rasau Jaya, Kabupaten Kubu Raya, Provinsi Kalimantan Barat. Pengambilan sampel air tanah dilakukan pada saat sebelum pemupukkan pada tanggal 2 April 2014, kemudian pemupukkan dilakukan pada sore hari tanggal 25 Mei 2014, dan pengambilan sampel setelah 3 (tiga) hari pemupukkan tepatnya hari ke-4 pada pagi hari tanggal 29 Mei 2014.

\section{A. Pengumpulan Data}

Pengumpulan data primer dilakukan dengan survei lokasi penelitian, pengukuran elevasi tanah, kedalaman ke muka air tanah, pengambilan sampel air dengan metode contoh gabungan waktu dan tempat, pengujian kualitas air tanah. Data sekunder yang digunakan antara lain berupa peta (peta administrasi dan peta lokasi penelitian).

\section{B. Pengambilan Sampel}

Penggalian 25 (dua puluh lima) buah sumur pantau dengan masing-masing titik berjarak $\pm 50 \mathrm{~m}$ di dalam areal lokasi studi dan diambil 5 (lima) buah sampel kualitas air tanah secara diagonal (A1, B2, C3, D4, dan E5). Penggalian 25 (dua puluh lima) buah sumur galian dilakukan dengan membenamkan pipa PVC berdiameter 4 inchi sepanjang $50 \mathrm{~cm}$ ke dalam tanah sampai keluar air tanah.

\section{Analisis Data}

Analisis data dilakukan dengan pengujian sampel air. Hasil berupa data kualitas air yang telah diperoleh dari analisis di laboratorium disajikan dalam bentuk tabel, grafik, dan gambar (peta kontur) membandingkan dengan baku mutu kualitas air pada Peraturan Pemerintah Republik Indonesia Nomor 82 Tahun 2001 untuk klasifikasi mutu air kelas II dan membandingkan antara kualitas air tanah pada saat sebelum pemupukkan dan setelah pemupukkan. Tinggi muka air tanah diperoleh dari hasil selisih tinggi permukaan tanah 
(elevasi) dengan kedalaman muka air tanahnya. Kontur air tanah dan arah aliran air tanah diperoleh berdasarkan pengukuran tinggi muka air tanah. Data tinggi muka air tanah ini selanjutnya akan digunakan dalam pembuatan peta kontur (preatik). Setelah pembuatan peta kontur (preatik) maka dibuat profil potongan melintang dan memanjang untuk mengetahui arah aliran air tanah secara detail. Profil elevasi tanah dan kedalaman muka air tanah dibuat dengan menggunakan software AutoCad versi 2008.

\section{HASIL DAN PEMBAHASAN}

\section{A. Analisis Kualitas Air Tanah}

a. Parameter Nitrogen (N)

Berikut hasil analisa air parameter Nitrat $\left(\mathrm{NO}_{3}\right)$ dalam Tabel 2 (Hasil Analisis, 2014):

Tabel 1. Nilai Parameter Nitrogen (N)

\begin{tabular}{|c|c|c|c|c|c|}
\hline \multirow[t]{2}{*}{ No. } & \multirow{2}{*}{$\begin{array}{c}\text { Titik } \\
\text { Sampel }\end{array}$} & \multirow{2}{*}{ Koordinat } & \multirow{2}{*}{$\begin{array}{c}\text { Sebelum } \\
\text { Pemupukkan } \\
\text { (mg/l) }\end{array}$} & \multirow{2}{*}{$\begin{array}{c}\text { Setelah } \\
\text { Pemupukkan } \\
\text { (mg/l) }\end{array}$} & $\begin{array}{l}\text { PP No. } 82 \text { tahun } \\
2001\end{array}$ \\
\hline & & & & & Kelas II \\
\hline 1 & $\mathrm{~A} 1$ & $\begin{array}{l}\text { E } 109^{\circ} 22^{\prime} 3.4^{\prime \prime} \\
\text { S } 00^{\circ} 13^{\prime} 56^{\prime \prime}\end{array}$ & 29,20 & 68,09 & \multirow{5}{*}{$\begin{array}{l}\text { Kadar maksimum } \\
\text { yang } \\
\text { diperbolehkan } \\
\text { Nitrate sebagai } \mathrm{N} \\
=10 \mathrm{mg} / \mathrm{l} \\
\text { Kelas II untuk } \\
\text { mengairi } \\
\text { pertanaman }\end{array}$} \\
\hline 2 & B2 & $\begin{array}{l}\text { E } 109^{\circ} 22^{\prime} 1.3^{\prime \prime} \\
\text { S } 00^{\circ} 13^{\prime} 56.4^{\prime \prime}\end{array}$ & 29,58 & 77,45 & \\
\hline 3 & C3 & $\begin{array}{l}\text { E } 109^{\circ} 21^{\prime} 58.9^{\prime \prime} \\
\text { S } 00^{\circ} 13^{\prime} 56.9^{\prime \prime}\end{array}$ & 45,50 & 57,45 & \\
\hline 4 & D4 & $\begin{array}{l}\text { E } 109^{\circ} 21^{\prime} 56.6^{\prime \prime} \\
\text { S } 00^{\circ} 13^{\prime} 57.4^{\prime \prime}\end{array}$ & 95,56 & 116,17 & \\
\hline 5 & E5 & $\begin{array}{l}\text { E } 109^{\circ} 21^{\prime} 54.7^{\prime \prime} \\
\text { S } 00^{\circ} 13^{\prime} 57.4^{\prime \prime}\end{array}$ & 52,81 & 77,45 & \\
\hline
\end{tabular}

Nilai konsentrasi tertinggi sebesar $95,56 \mathrm{mg} / \mathrm{l}$ saat sebelum pemupukkan dan 116,17 $\mathrm{mg} / \mathrm{l}$ pada saat setelah pemupukkan pada titik D4. Hal ini dikarenakan pada titik D4 merupakan titik yang tidak jauh berada di dekat saluran buatan yang merupakan residu akibat penggunaan pupuk dan berbagai sampah aktifitas pertanian yang menyerap dalam air tanah dan mengalir ke saluran. Nitrat dipengaruhi oleh tumbuhan, akar tumbuhan menyerap nitrat selanjutnya oleh bakteri denitrifikan, nitrat diubah menjadi ammonia kembali dan ammonia diubah menjadi nitrogen yang dilepaskan kembali ke udara. Nilai konsentrasi Nitrogen $(\mathrm{N})$ terendah saat sebelum dan setelah pemupukkan terdapat pada titik A1 sebesar $29,20 \mathrm{mg} / \mathrm{l}$ dan titik C3 sebesar $57,45 \mathrm{mg} / \mathrm{l}$. Hal ini disebabkan titik A1 merupakan titik yang dekat dengan saluran tersier dan aliran air tanah mengalir ke arah timur di mana saluran tersier berada sehingga air mengalir dan mengalami rembesan ke arah titik $A 1$, sedangkan titik $\mathrm{C} 3$ tidak memiliki aktifitas pertanian tetapi mengalami rembesan konsentrasi Nitrogen akibat pemupukkan di sekitar titik C3.

Tingginya Nitrogen yang di dalam tubuh menjadi nitrat berubah menjadi nitrit dan berikatan dengan Oksigen bereaksi dengan Hemoglobin dan membentuk Methemoglobin (metHb) dalam darah sehingga wajah bayi menjadi biru karena kurang oksigen atau sering disebut "blue babies" (Soemirat, 1994). 


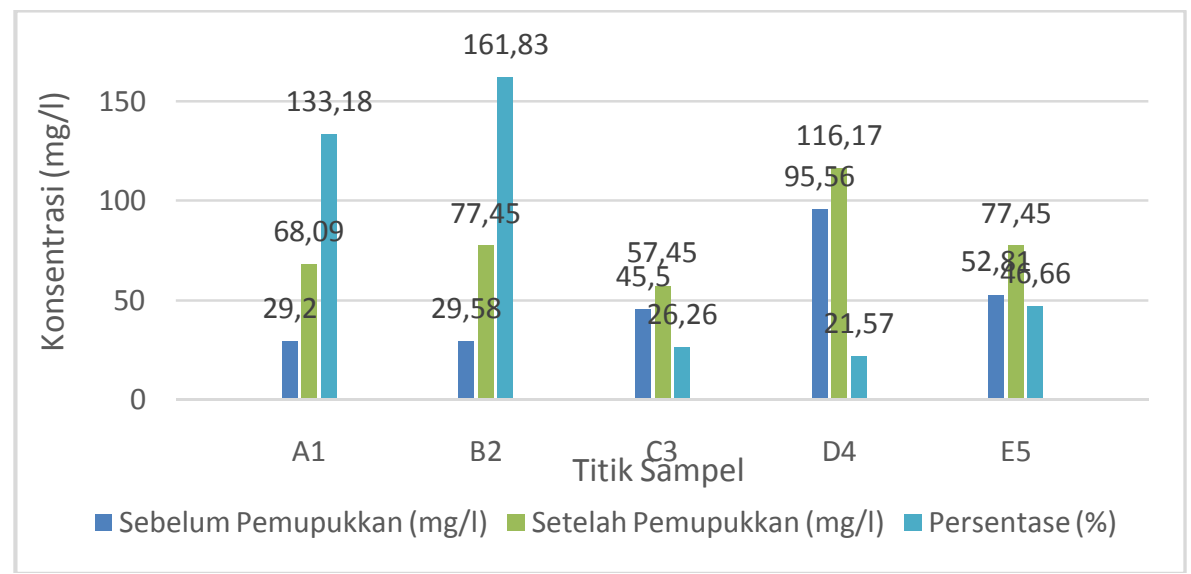

Gambar 1.Grafik parameter Nitrogen (N)

Pada Gambar 1 titik sampel B2 memiliki tingkat kenaikkan konsentrasi Nitrogen tertinggi dari $29,58 \mathrm{mg} / \mathrm{l}$ menjadi $77,45 \mathrm{mg} / \mathrm{l}$ sehingga terjadi selisih sebesar $47,87 \mathrm{mg} / \mathrm{l}$. Hal ini disebabkan pada titik B2 berada pada lokasi yang penuh dengan aktivitas penanaman padi, sehingga diperkirakan terjadi pemupukkan secara penuh juga pada titik tersebut. Menurut Sianipar (2001), pemupukkan yang berlangsung secara terus-menerus dengan jumlah yang banyak akan mengakibatkan jumlah Nitrogen di tanah meningkat.

\section{b. Parameter Fosfor (P)}

Berikut hasil analisa air parameter Fosfat $\left(\mathrm{PO}_{4}\right)$ dalam Tabel 3 (Hasil Analisis, 2014):

Tabel 2. Nilai Parameter Fosfor (P)

\begin{tabular}{|c|c|c|c|c|c|}
\hline \multirow[t]{2}{*}{ No. } & \multirow{2}{*}{$\begin{array}{l}\text { Titik } \\
\text { Sampel }\end{array}$} & \multirow[t]{2}{*}{ Koordinat } & \multirow{2}{*}{$\begin{array}{c}\text { Sebelum } \\
\text { Pemupukkan } \\
\text { (mg/l) }\end{array}$} & \multirow{2}{*}{$\begin{array}{c}\text { Setelah } \\
\text { Pemupukkan } \\
\text { (mg/l) }\end{array}$} & $\begin{array}{l}\text { PP No. } 82 \text { tahun } \\
2001\end{array}$ \\
\hline & & & & & Kelas II \\
\hline 1 & $\mathrm{~A} 1$ & $\begin{array}{l}\text { E } 109^{\circ} 22^{\prime} 3.4^{\prime \prime} \\
\text { S } 00^{\circ} 13^{\prime} 56^{\prime \prime}\end{array}$ & 1,03 & 13,13 & \multirow{5}{*}{$\begin{array}{c}\text { Kadar } \\
\text { maksimum yang } \\
\text { diperbolehkan } \\
\text { Total Phosphate } \\
\text { sebagai } \mathrm{P}=0,2 \\
\text { mg/l Kelas II } \\
\text { untuk mengairi } \\
\text { pertanaman }\end{array}$} \\
\hline 2 & B2 & $\begin{array}{l}\text { E } 109^{\circ} 22^{\prime} 1.3^{\prime \prime} \\
\text { S } 00^{\circ} 13^{\prime} 56.4^{\prime \prime}\end{array}$ & 1,12 & 20,52 & \\
\hline 3 & C3 & $\begin{array}{l}\text { E } 109^{\circ} 21^{\prime} 58.9^{\prime \prime} \\
\text { S } 00^{\circ} 13^{\prime} 56.9^{\prime \prime}\end{array}$ & 1,12 & 7,1 & \\
\hline 4 & D4 & $\begin{array}{l}\text { E } 109^{\circ} 21^{\prime} 56.6^{\prime \prime} \\
\text { S } 00^{\circ} 13^{\prime} 57.4^{\prime \prime}\end{array}$ & 1,89 & 49,03 & \\
\hline 5 & E5 & $\begin{array}{l}\text { E } 109^{\circ} 21^{\prime} 54.7^{\prime \prime} \\
\text { S } 00^{\circ} 13^{\prime} 57.4^{\prime \prime}\end{array}$ & 4,98 & 45,61 & \\
\hline
\end{tabular}

Pada Tabel 2, titik sampel E5 memiliki nilai konsentrasi Fosfor tertinggi saat sebelum pemupukkan sebesar $4,98 \mathrm{mg} / \mathrm{l}$ dan saat setelah pemupukkan pada titik D4 memiliki nilai konsentrasi Fosfor tertinggi saat setelah pemupukkan sebesar $49,03 \mathrm{mg} / \mathrm{l}$. Pada titik E5 terjadi nilai konsentrasi tertinggi tetapi masih di bawah baku mutu, sedangkan pada titik D4 terjadi nilai konsentrasi tinggi dikarenakan adanya residu dari pemupukkan dan sampah yang mengandung unsur hara Fosfor dalam fosfat sehingga meningkatkan kadar Fosfat dalam tanah. Semakin banyak residu pemupukkan dan sampah yang mengandung unsur Fosfor semakin besar pula kandungan $\mathrm{P}$ dalam tanah. Nilai konsentrasi Fosfor terendah saat sebelum pemupukkan terdapat pada titik A1 sebesar $1,03 \mathrm{mg} / \mathrm{l}$ dan saat setelah pemupukkan terdapat pada titik C3 sebesar 7,10 mg/l.

Keberadaan fosfat yang berlebihan pada badan air menyebabkan suatu fenomena yang disebut eutrofikasi (pengkayaan nutrien). Kandungan fosfor yang berlebih dapat 
mengganggu kesehatan manusia seperti kerusakan ginjal dan osteoporosis. Bahkan jenis fosfor putih juga dapat menyebabkan kulit terbakar dengan uapnya bisa menyebabkan kerusakan hati, jantung atau ginjal (Effendi, 2003).

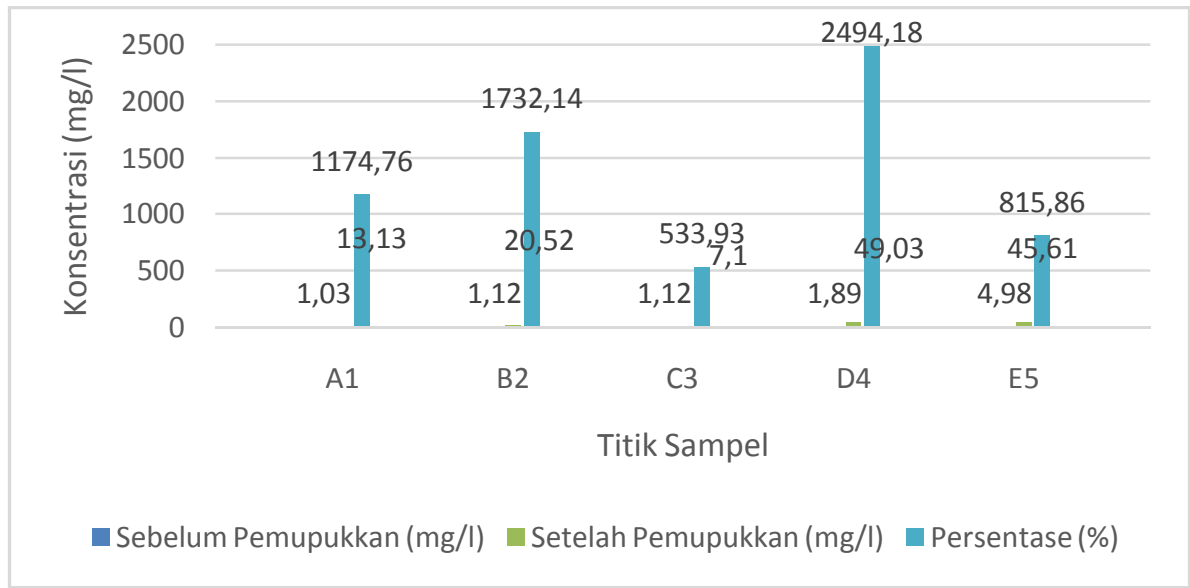

Gambar 2. Grafik parameter Fosfor (P)

Dari Gambar 2 titik sampel D4 memiliki tingkat kenaikkan konsentrasi Fosfor tertinggi dari $1,89 \mathrm{mg} / \mathrm{l}$ menjadi $49,03 \mathrm{mg} / \mathrm{l}$ sehingga terjadi selisih sebesar $47,14 \mathrm{mg} / \mathrm{l}$.Pada titik sampel C3 memiliki tingkat kenaikan konsentrasi Fosfor terendah dari 1,12 mg/l menjadi 7,1 mg/l sehingga didapat selisih sebesar 5,98 $\mathrm{mg} / \mathrm{l}$.

\section{c. Parameter Kalium (K)}

Berikut hasil analisa air parameter Kalium (K) dalam Tabel 4 (Hasil Analisis, 2014):

Tabel 3. Nilai Parameter Kalium (K)

\begin{tabular}{|c|c|c|c|c|}
\hline No. & $\begin{array}{c}\text { Titik } \\
\text { Sampel }\end{array}$ & Koordinat & $\begin{array}{c}\text { Sebelum } \\
\text { Pemupukkan } \\
\text { (mg/I) }\end{array}$ & $\begin{array}{c}\text { Setelah } \\
\text { Pemupukkan } \\
\text { (mg/I) }\end{array}$ \\
\hline 1 & A1 & $\begin{array}{l}\mathrm{E} 109^{\circ} 22^{\prime} 3.4^{\prime \prime} \\
\mathrm{S} 00^{\circ} 13^{\prime} 56^{\prime \prime}\end{array}$ & 8,4 & 30,4 \\
\hline 2 & $\mathrm{~B} 2$ & $\begin{array}{l}\mathrm{E} 109^{\circ} 22^{\prime} 1.3^{\prime \prime} \\
\mathrm{S} 00^{\circ} 13^{\prime} 56.4^{\prime \prime}\end{array}$ & 8,4 & 34,92 \\
\hline 3 & $\mathrm{C} 3$ & $\begin{array}{l}\mathrm{E} 109^{\circ} 21^{\prime} 58.9^{\prime \prime} \\
\mathrm{S} 00^{\circ} 13^{\prime} 56.9^{\prime \prime}\end{array}$ & 8,4 & 23,9 \\
\hline 4 & $\mathrm{D} 4$ & $\begin{array}{l}\mathrm{E} 109^{\circ} 21^{\prime} 56.6^{\prime \prime} \\
\mathrm{S} 00^{\circ} 13^{\prime} 57.4^{\prime \prime}\end{array}$ & 22,25 & 44,79 \\
\hline 5 & $\mathrm{E} 5$ & $\begin{array}{l}\mathrm{E} 109^{\circ} 21^{\prime} 54.7^{\prime \prime} \\
\mathrm{S} 00^{\circ} 13^{\prime} 57.4^{\prime \prime}\end{array}$ & 13,84 & 33,84 \\
\hline
\end{tabular}

Dari Tabel 4, titik sampel D4 memiliki nilai kadar Kalium (K) tertinggi saat sebelum dan setelah pemupukkan dengan nilai masing-masing $22,25 \mathrm{mg} / \mathrm{l}$ dan $44,79 \mathrm{mg} / \mathrm{l}$. Nilai kadar Kalium terendah saat sebelum dan setelah pemupukkan terletak pada titik C3 dengan masingmasing nilai sebesar $8,40 \mathrm{mg} / \mathrm{l}$ dan 23,90 mg/l. Hal ini disebabkan titik C3 merupakan titik yang tidak mengalami aktivitas pertanian (penanaman dan pemupukkan), tetapi berasal dari rembesan pemupukkan yang mengandung unsur hara Kalium (K) yang tersebar melalui air tanah. Kalium hilang dari tanah melalui mekanisme penyerapan tanaman, pelindian air permukaan. 


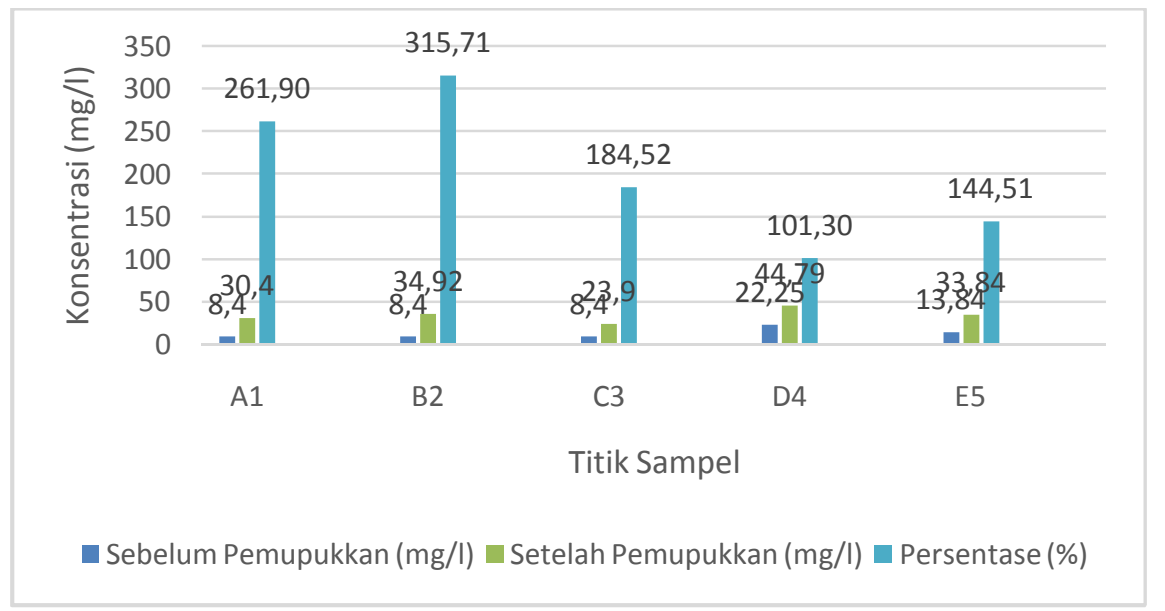

Gambar 3. Grafik parameter Kalium (K)

Dari Gambar 3 titik sampel B2 memiliki tingkat kenaikkan konsentrasi Kalium (K) tertinggi dari $8,4 \mathrm{mg} / \mathrm{I}$ menjadi $34,92 \mathrm{mg} / \mathrm{I}$ sehingga terjadi selisih sebesar $26,52 \mathrm{mg} / \mathrm{l}$. Hal ini disebabkan pada titik B2 memiliki lokasi yang penuh dengan aktivitas penanaman padi sehingga pemakaian pupuk yang berlebihan tidak terserap ke tanaman melainkan hilang oleh sebagian besar pengangkutan air tanah. Pada titik sampel C3 memiliki tingkat kenaikan konsentrasi Kalium (K) terendah dari $8,4 \mathrm{mg} / \mathrm{l}$ menjadi $23,9 \mathrm{mg} / \mathrm{l}$ sehingga terjadi selisih sebesar $15,5 \mathrm{mg} / \mathrm{l}$.

B. Hubungan Elevasi Tanah, Kedalaman ke Muka Air Tanah, dan Parameter N, P, dan K a. Parameter Nitrogen (N)

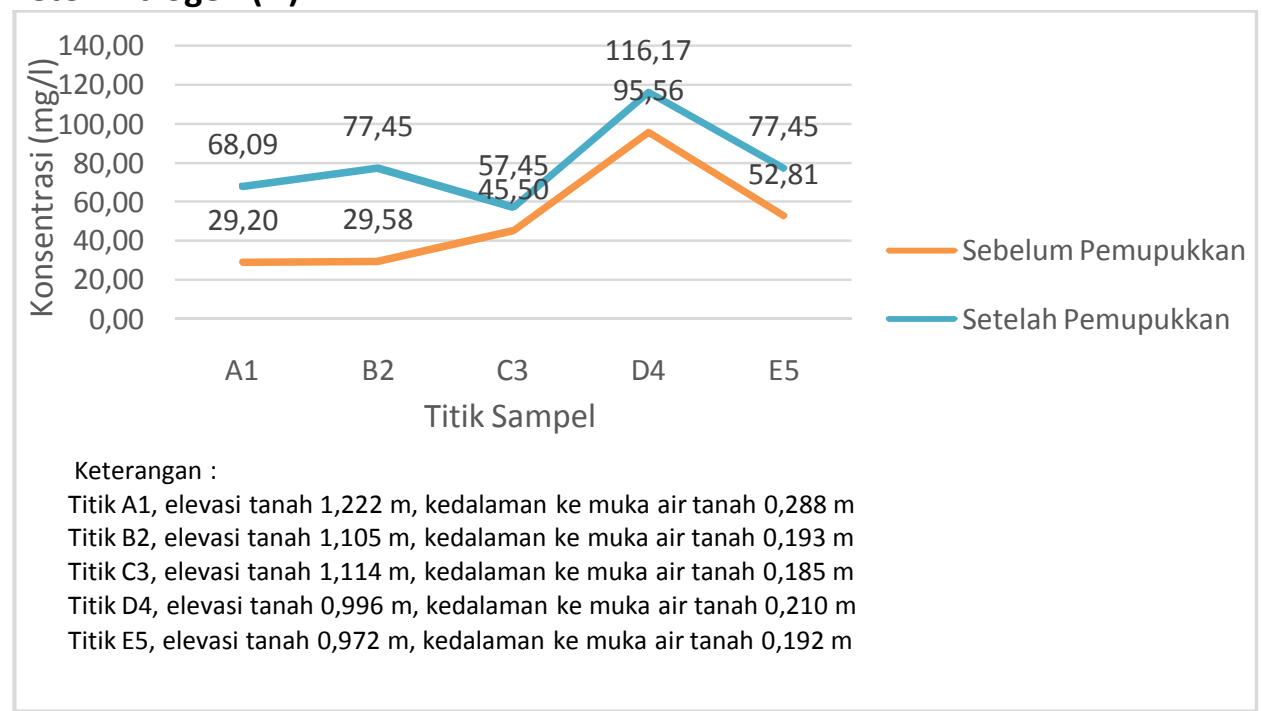

Gambar 5.Grafik parameter Nitrogen (N)

Gambar 5 menunjukkan konsentrasi Nitrogen dari titik A1 sampai titik E5 pada saat sebelum pemupukkan dan setelah pemupukkan. Terjadi peningkatan konsentrasi Nitrogen di titik D4 saat sebelum maupun setelah pemupukkan. Konsentrasi Nitrogen yang tinggi disebabkan rendahnya elevasi tanah di titik tersebut yaitu 0,996 m dengan kedalaman ke muka air tanah cukup rendah yaitu 0,210 m sehingga aliran air tanah dengan mudah mengalir ke elevasi tanah yang rendah. 


\section{b. Parameter Fosfor (P)}

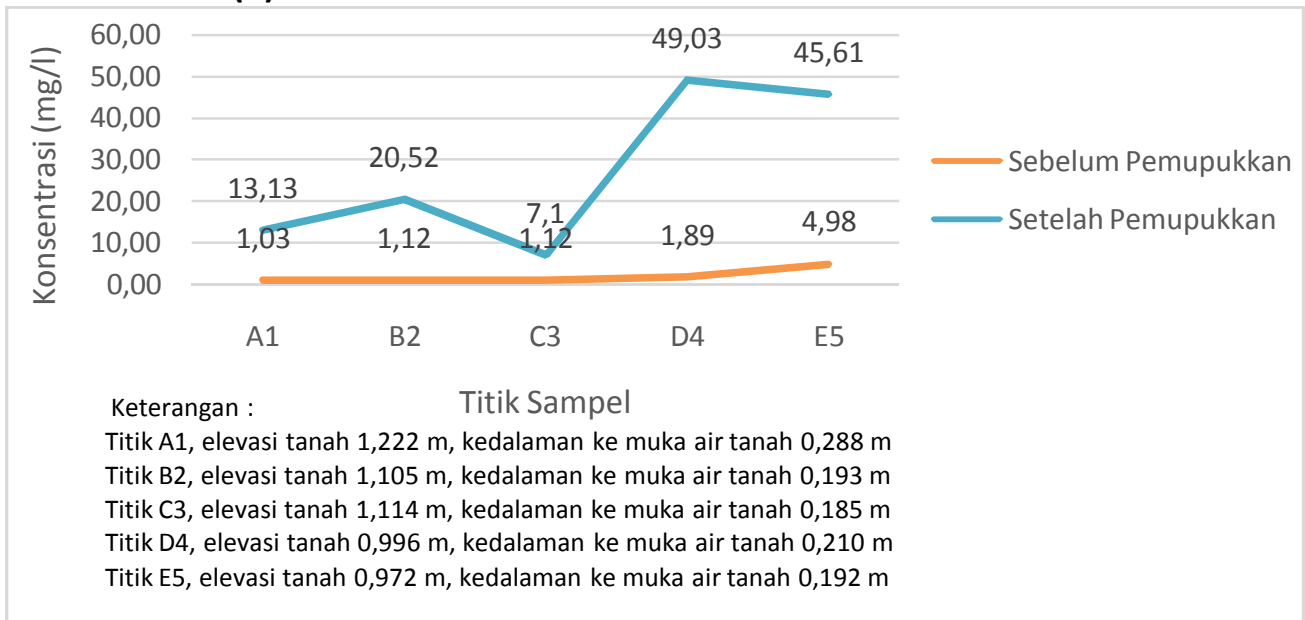

Gambar 6. Grafik parameter Fosfat (P)

Gambar 6. menunjukkan konsentrasi Fosfat sebelum pemupukkan dan setelah pemupukkan. Pada saat sebelum pemupukkan menunjukkan nilai konsentrasi tidak berbeda jauh dari titik 1 ke titik berikutnya, namun terjadi peningkatan $3 \mathrm{mg} / \mathrm{l}$ pada titik E5. Pada saat setelah pemupukkan konsentrasi Fosfat mengalami meningkat di titik B2 dengan elevasi tanah yaitu 1,105 m dan kedalaman ke muka air tanah yaitu 0,193 m kemudian menurun di titik C3 dengan elevasi tanah yaitu 1,114 m dan kedalaman ke muka air tanah yaitu 0,185 m dan kembali meningkat tinggi di titik D4.

\section{c. Parameter Kalium (K)}

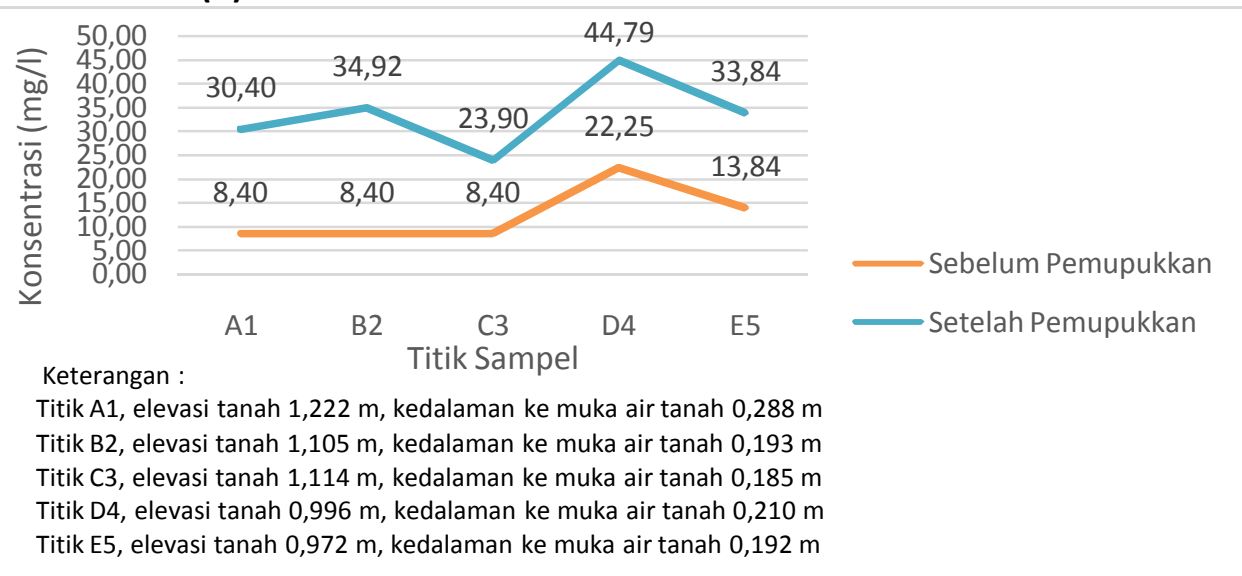

Gambar 7.Grafik parameter Kalium (K)

Gambar 7. menunjukkan konsentrasi Kalium sebelum pemupukkan dan setelah pemupukkan. Pada saat sebelum pemupukkan titik A1 sampai titk C3 memiliki nilai konsentrasi yang sama yaitu $8,40 \mathrm{mg} / \mathrm{l}$. Namun setelah pemupukkan titik A1 sampai C3 memiliki konsentrasi yang berbeda yaitu pada titik $\mathrm{A} 1$ dengan elevasi tanah 1,222 $\mathrm{m}$ dan kedalaman ke muka air tanah 0,288 m sebesar 30,40 mg/l, pada titik B2 dengan elevasi tanah 1,105 m dan kedalaman ke muka air tanah 0,193 m sebesar $34,92 \mathrm{mg} / \mathrm{l}$, dan pada titik C3 dengan elevasi tanah 1,114 m dan kedalaman ke muka air tanah 0,185 m sebesar $23,90 \mathrm{mg} / \mathrm{l}$. Pada titik D4 mengalami peningkatan konsentrasi dan penurunan konsentrasi kembali di titik E5 dengan elevasi tanah 0,972 m dan kedalaman ke muka air tanah yaitu 0,192 m. 


\section{Pola Aliran Air Tanah dan Pola Sebaran Kontaminan \\ a. Pola Aliran Air Tanah}

Dari hasil pengukuran kedalaman ke muka air tanah, elevasi tanah dan elevasi muka air tanah yang kemudian di gambarkan dalam peta kontur aliran air tanah. Berikut tampilan dalam gambar pola aliran air tanah pada Gambar 8:

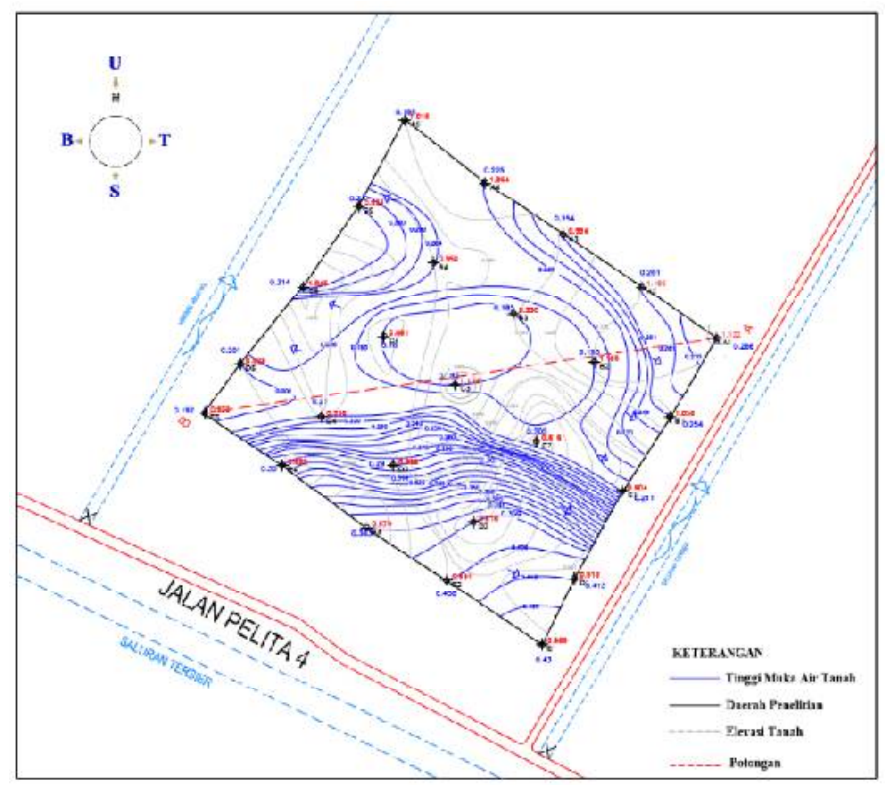

Gambar 8. Pola Aliran Air Tanah

Dari Gambar 8 dapat dilihat bahwa titik A1, A2, A3, A4, B1, B2, B3, C1, C2, C3, D1dan C1 aliran air tanah sebagian besar mengarah ke timur menuju ke arah utara dan titik A5, B4, B5, C4, C5, D5, dan E5 mengalir ke arah barat yang berada di sebelah kiri lokasi penelitan menuju ke arah utara. Aliran air tanah pada titik tersebut mengalir menuju saluran tersier membawa zat pencemar secara gravitasi dari tinggi ke rendah.

\section{b. Analisis Pola Sebaran Kontaminan}

1.Parameter Nitrogen $(\mathrm{N})$

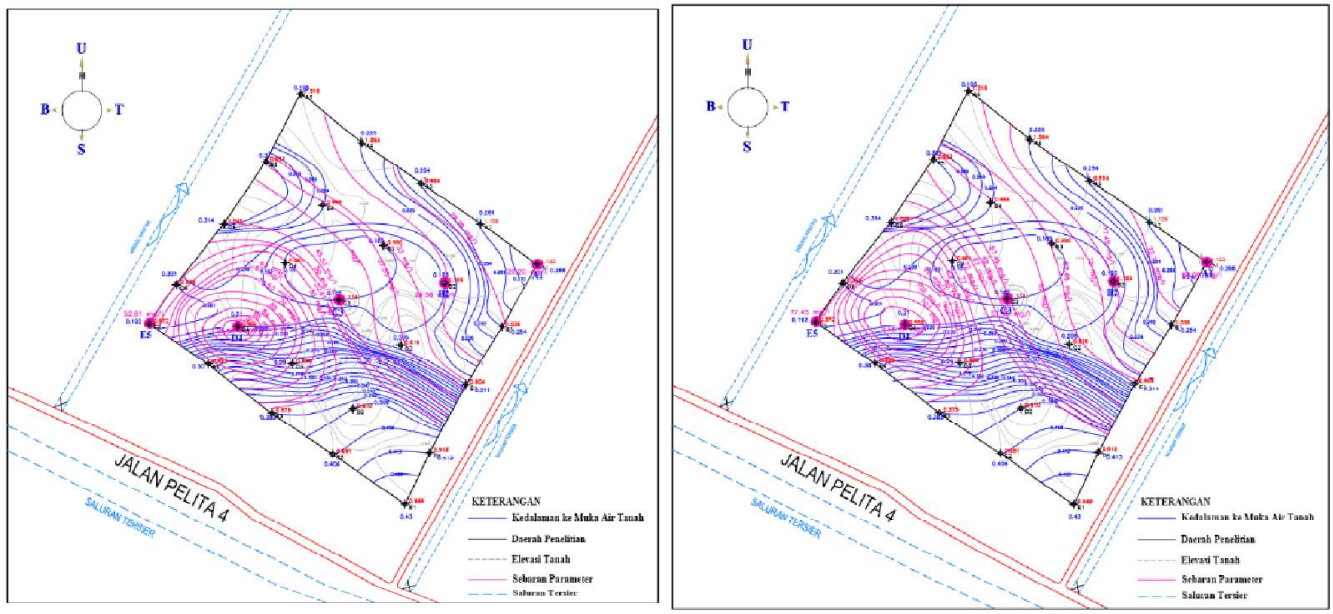

Gambar 10. Pola sebaran parameter Nitrogen (N) sebelum dan setelah pemupukkan 


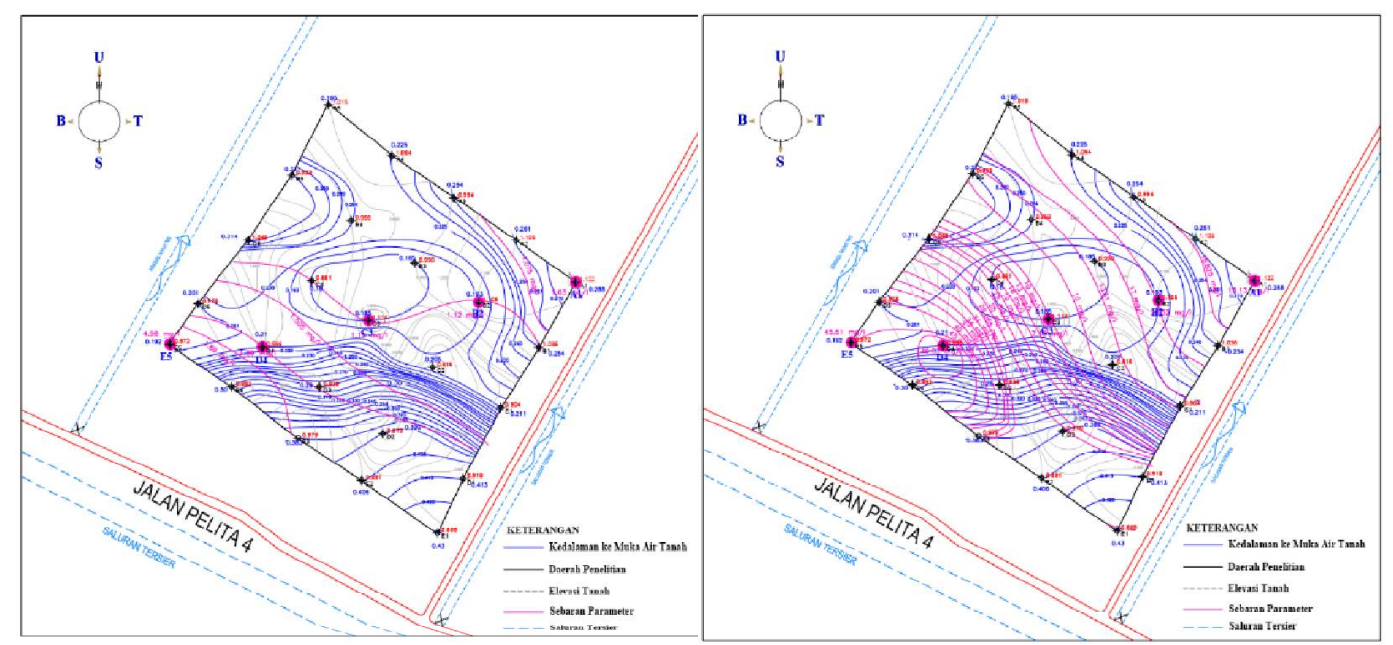

Gambar 11. Pola sebaran parameter fosfor (P) sebelum dan setelah pemupukkan
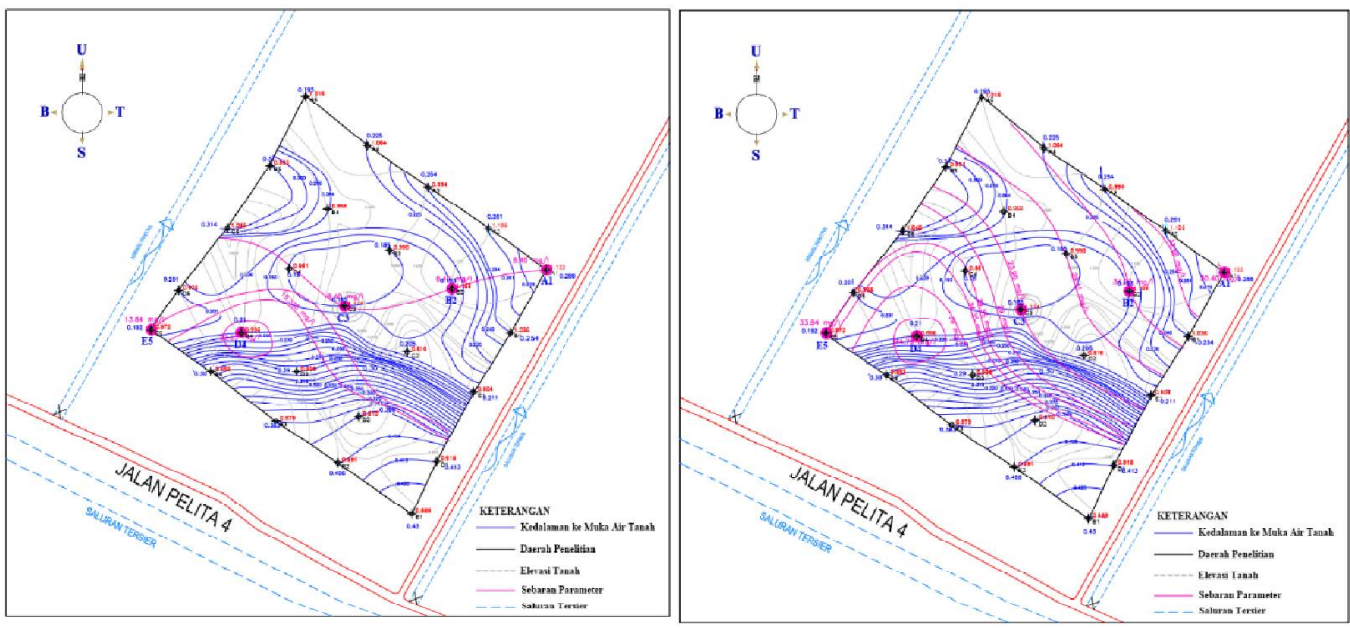

Gambar 12. Pola sebaran parameter kalium (K) sebelum dan setelah pemupukkan

Pada saat sebelum pemupukkan Nitrogen dengan interval $4 \mathrm{mg} / \mathrm{l}$, Fosfor dengan interval 0,4 mg/l, dan Kalium dengan interval $7 \mathrm{mg} / \mathrm{l}$. Sedangkan pada saat setelah pemupukkan Nitrogen dengan interval $5 \mathrm{mg} / \mathrm{l}$, Fosfor dengan interval $3 \mathrm{mg} / \mathrm{l}$, dan Kalium dengan interval $5 \mathrm{mg} / \mathrm{l}$. Pola sebaran ketiga parameter ( $\mathrm{N}, \mathrm{P}$, dan $\mathrm{K})$ mengikuti aliran muka air tanah. Aliran air tanah yang mengalir mengikuti ketinggian elevasi tanah, air mengalir dari tempat yang tinggi ke tempat yang rendah membawa kontaminan dan terjadi penyebaran kontaminan pada elevasi tanah yang relatif rendah kemudian menyerap ke tanah dan sebagian mengalir menuju saluran tersier. Pada lokasi penelitian kondisi topografi tanah yang relatif datar menyebabkan konsentrasi zat pencemar menyebar ke segala arah, sehingga kualitas air tanah di lokasi penelitian rata-rata telah tercemar. Pupuk NPK yang digunakan secara terusmenerus tanpa ada pengendalian atau pengontrolan akan mempengaruhi kualitas air tanah secara berkala, pengaruh inilah yang akan memicu peningkatan konsentrasi nitrat, fosfat, dan kalium dalam tanah, semakin rendah elevasi tanah maka semakin besar pengaruh pupuk NPK yang terserap ke tanah. 


\section{Kesimpulan}

1. Berdasarkan hasil penelitian yang telah dilakukan dapat disimpulkan bahwa konsentrasi $\mathrm{N}, \mathrm{P}$, dan K (Nitrogen, Fosfor, dan Kalium) pada air tanah melebihi baku mutu PP RI No.82 Tahun 2001 kelas II, di mana titik konsentrasi tertinggi berada di titik D4.

2. Hasil analisis kualitas air tanah dengan persentase kenaikan tertinggi :

a. Konsentrasi dari Konsentrasi Nitrogen (N) di titik B2 saat sebelum pemupukkan sebesar sebesar $29,58 \mathrm{mg} / \mathrm{l}$ dan saat setelah pemupukkan sebesar $77,45 \mathrm{mg} / \mathrm{l}$ dengan persentase kenaikan $161,83 \%$.

b. Konsentrasi Fosfor (P) di titik D4 tertinggi saat sebelum pemupukkan sebesar 1,89 mg/l dan saat setelah pemupukkan 49,03 $\mathrm{mg} / \mathrm{I}$ dengan persentase kenaikan $2494,18 \%$.

c. Konsentrasi Kalium (K) di titik B2 tertinggi saat sebelum pemupukkan sebesar 8,4 mg/l dan saat setelah pemupukkan sebesar $34,92 \mathrm{mg} / \mathrm{l}$ dengan persentase kenaikan $315,71 \%$.

3. Aliran air tanah di lokasi penelitian mengikuti ketinggian elevasi tanah, mengalir tempat tinggi menuju ke tempat yang rendah membawa kontaminan dan terjadi penyebaran kontaminan pada elevasi tanah yang relatif rendah. Kerapatan garis kontur di beberapa titik menunjukkan berada pada dataran yang relatif tinggi dan memiliki penyebaran kontaminan yang tinggi, sebaliknya pada beberapa titik yang memiliki kontur pola sebaran yang jarang menunjukkan berada pada dataran yang relatif rendah dan memiliki pola penyebaran kontaminan yang tidak tinggi.

\section{Ucapan Terima Kasih}

Penulis mengucapkan terima kasih kepada Allah SWT, kedua orang tua, dosen pembimbing Dr. Ir. Marsudi, M.Sc dan Dian RahayuJati, ST, M.Si, Laboratorium Survei dan Pemetaan Fakultas Teknik UNTAN, Laboratorium Kimia dan Kesuburan Tanah Fakultas Pertanian UNTAN, kepada teman-teman Teknik Lingkungan 2010 serta semua pihak yang telah berperan dalam proses dan penyelesaian penelitian ini.

\section{Referensi}

Effendi, H., 2003. Telaah Kualitas Air, Bagi Pengelolaan Sumber Daya dan Lingkungan Perairan, Penerbit Kanisius. Yogyakarta.

Pemerintah Republik Indonesia. 2001. Peraturan Pemerintah Nomor: 82 Tahun 2001 (PP 82/2001) Tentang Pengelolaan Kualitas Air dan Pengendalian Pencemaran Air, Jakarta

Sianipar,W. 2011. Nitrogen Akibat Penggunaan Pupuk. Diakses tanggal 05/08/2014. http.//link. nitrogen. indeks//.com.

Soemirat, Juli, 1994. Kesehatan Lingkungan. Gajah Mada University Press, Yogyakarta. 